\title{
A new cavernicolous species of Typhloligidium Verhoeff, 1918 (Isopoda: Oniscidea: Ligiidae) from the Caucasus
}

\author{
Новый пещерный виА Typhloligidium Verhoeff, 1918 \\ (Isopoda: Oniscidea: Ligiidae) с Кавказа
}

\author{
Konstantin B. Gongalsky ${ }^{1}$, Stefano Taiti \\ К.Б. Гонгальский, С. Таити
}

\begin{abstract}
${ }^{1}$ A.N. Severtsov Institute of Ecology and Evolution, Russian Academy of Sciences, Leninsky prospekt 33, Moscow 119071, Russia. Email: gongalsky@gmail.com

Институт проблем экологии и эволюции им. А.Н. Северцова РАН, Ленинский пр-т, 33, Москва, 119071, Россия.

${ }^{2}$ Istituto per lo Studio degli Ecosistemi, Consiglio Nazionale delle Ricerche, Via Madonna del Piano 10, I-50019 Sesto Fiorentino, Florence, Italy. E-mail: stefano.taiti@ise.cnr.it
\end{abstract}

KEY WORDS: Isopoda, Oniscidea, Ligiidae, new species, cave, Kabardino-Balkaria, Caucasus, Russia.

КЛЮЧЕВЫЕ СЛОВА: Isopoda, Oniscidea, Ligiidae, новый вид, пещера, Кабардино-Балкария. Кавказ, Россия.

ABSTRACT. A new species of terrestrial isopod from a cave in northwestern Caucasus is described: Typhloligidium kovali sp.n. (Ligiidae). The diagnostic characters and the affinities of the new species within the troglobiontic genus Typhloligidium are discussed.

РЕЗЮМЕ. Приводится описание нового вида наземных изопод из пещеры на Северо-Западном Кавказе: Typhloligidium kovali sp.n. (Ligiidae). Обсуждаются диагностические признаки и сродство нового вида в пределах троглобионтного рода Typhloligidium.

\section{Introduction}

The terrestrial isopods of Russia are still poorly known, despite the numerous descriptions of species dating back to the 19th century and the studies of E.V. Borutzky during the middle of the last century. Since then only few publications dealing with woodlouse taxonomy from the Russian territory have appeared [e.g., Schmalfuss, 2003a; Khisametdinova \& Schmalfuss, 2012; Kuznetsova \& Gongalsky, 2012]. Certainly the territory of the Caucasus is one of the richest and most diverse as far as terrestrial isopods are concerned.

Cave fauna of the southern parts of the former USSR was quite well sampled by Soviet biospeleologists. Their collections of Oniscidea were studied and published by E.V. Borutzky in a series of papers [Borutzky, 1948, 1950, 1962, 1969, 1972, 1973, 1974, 1977]. He described several new genera and species from caves in the Crimea and Caucasus.

Recently, Dr. A.G. Koval, a Russian entomologist and biospeleologist from St. Petersburg, has investigated caves in the Caucasus and collected a large number of terrestrial isopods. Among these, a new species of the cavernicolous genus Typhloligidium Verhoeff, 1918 (Ligiidae) from a cave on the northern macroslope of the Caucasus has been discovered. Typhloligidium was previously only known from two species from various caves in the Crimea, Ukraine: T. coecum (Carl, 1904) (the type species) and T. karabijajlae Borutzky, 1962 [Schmalfuss, 2003b].

\section{Material and methods}

Specimens are stored in $70 \%$ ethanol and the identification is based on morphological characters alone. Terminology used in the species description is mainly after Vandel [1960]. The taxa are illustrated with figures prepared with the aid of a camera lucida mounted on Wild M5 or M20 microscope. The material is deposited in the collections of the Zoological Museum of the Moscow University (ZMMU) and the Museo di Storia Naturale dell'Università, Sezione di Zoologia "La Specola", Firenze (MZUF).

\section{Taxonomy}

Ligiidae

Genus Typhloligidium Verhoeff, 1918

Type species: Typhloligidium coecum (Carl, 1904), by monotypy.

DIAGNOSIS. Eyes and pigmentation absent. Dorsal surface smooth or slightly granulated. No piliferous fields on sides of rear margins of anterior pereonites. Frontal line absent, supra-antennal line distinct. Distal corners of pereonite 1 rounded; corners of pereonites 2-7 increasingly acute. Epimera of pleonites 3-5 reduced, with short posterior points. Telson with distal 

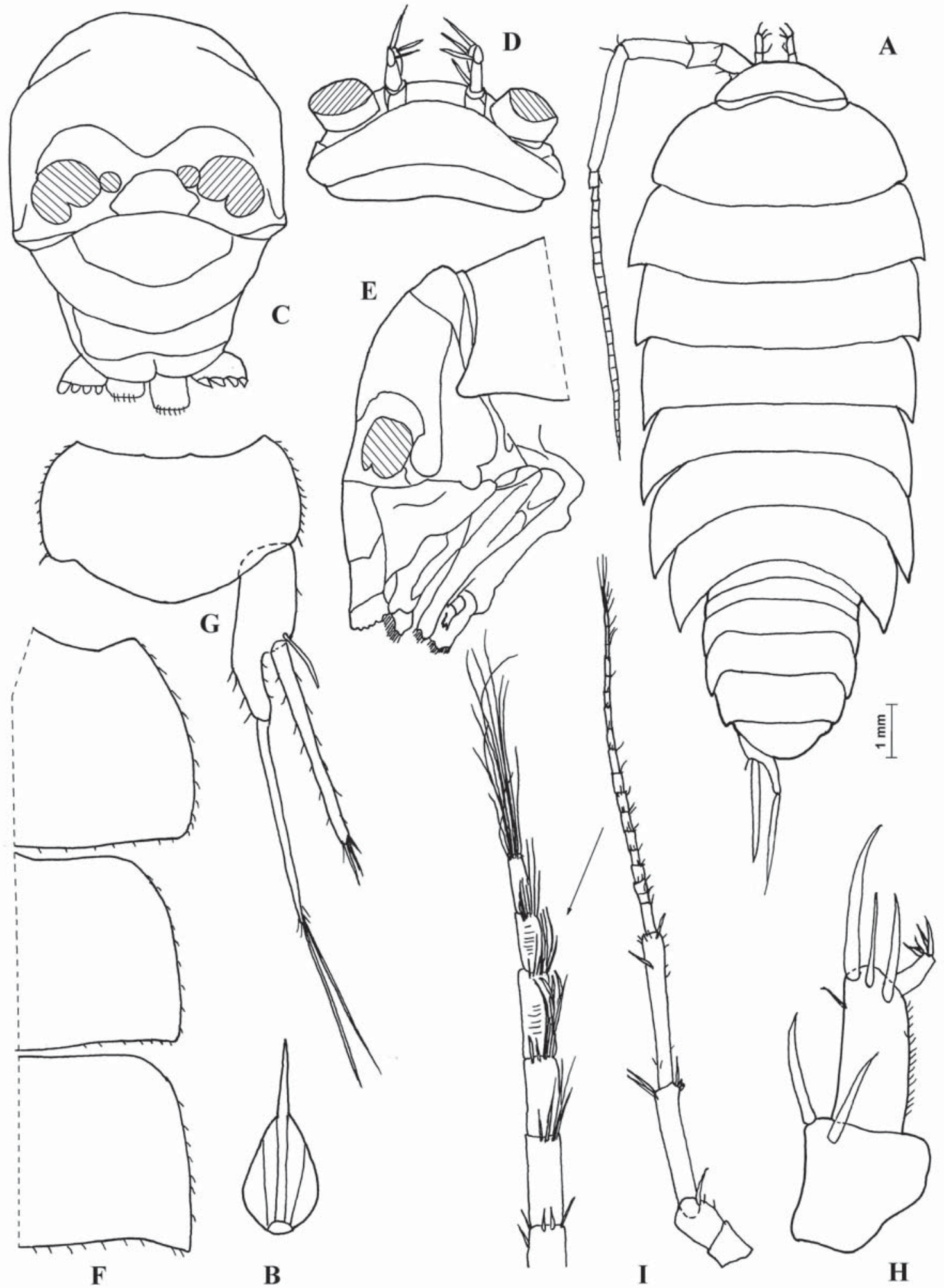

Fig. 1. Typhloligidium kovali sp.n., o paratype: A - animal in dorsal view; B - dorsal scale-seta; C - cephalon, frontal; D cephalon, dorsal; E - cephalon and pereonite 1, lateral; F - pereonites 1-3, right side; $\mathrm{G}$ - telson and right uropod; H - antennule; I antenna.

Рис. 1. Typhloligidium kovali sp.n., паратип : А — габитус сверху; В — дорсальная сета; C — голова спереди; D — голова сверху; Е — голова и переонит 1 сбоку; F — переониты 1-3, правая сторона; G — тельсон и правые уроподы; H — антеннула; I — антенна. 


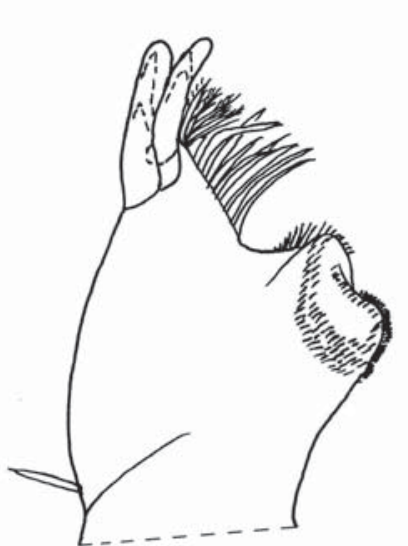

A

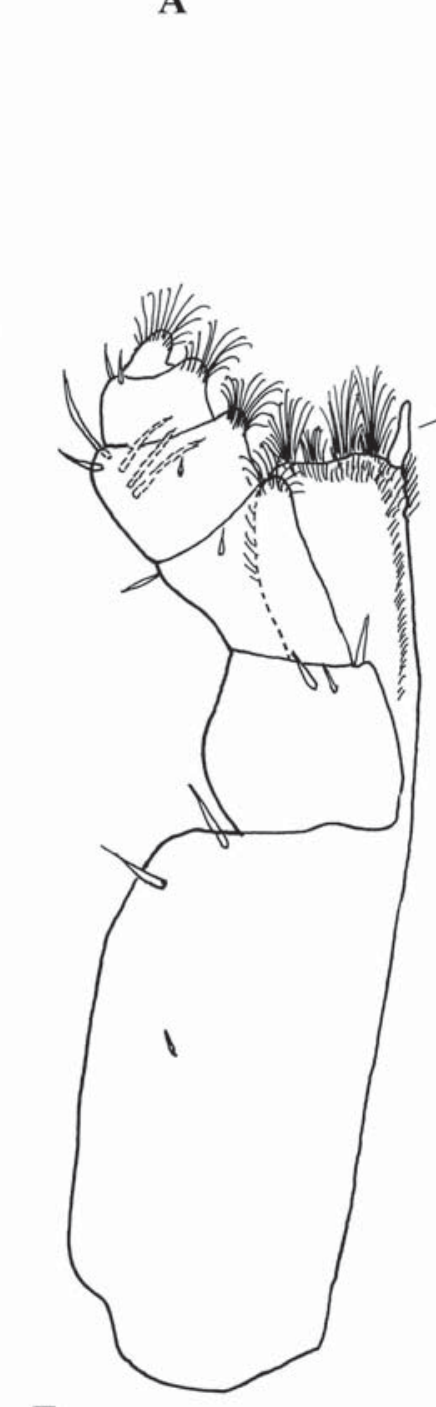

$\mathbf{E}$
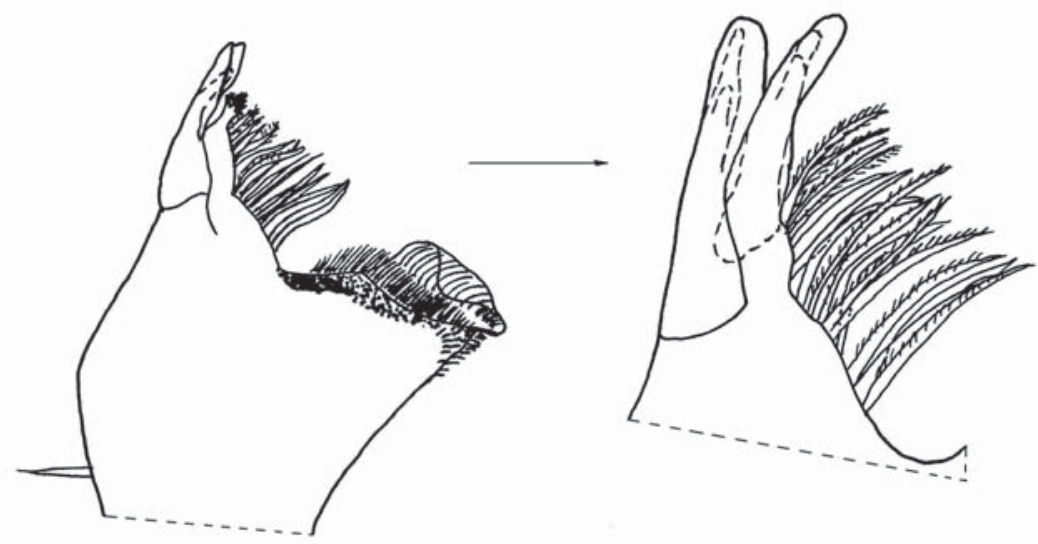

B
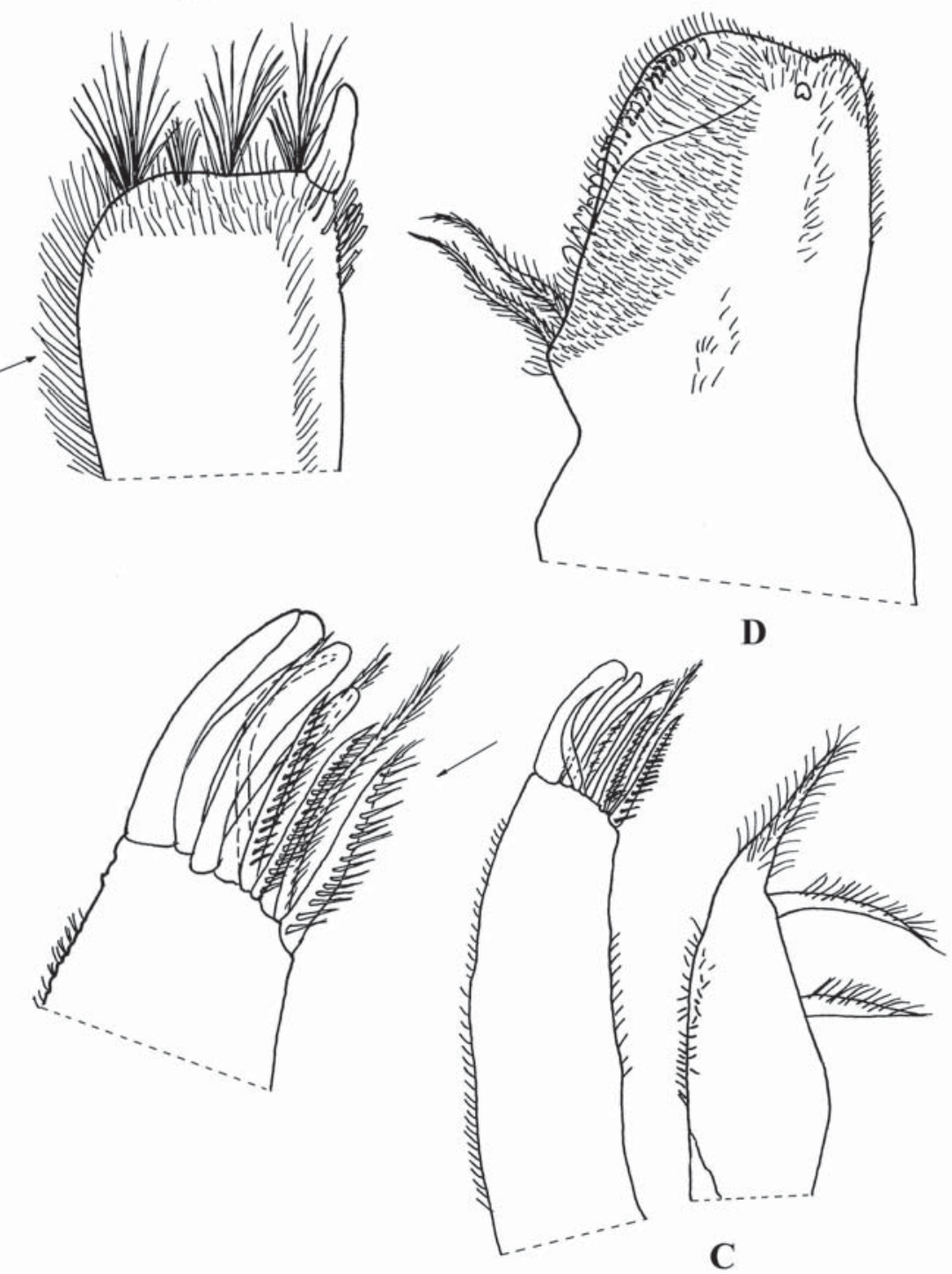

Fig. 2. Typhloligidium kovali sp.n., + paratype: A - right mandible; B - left mandible; C - maxillule; D - maxilla; E maxilliped.

Рис. 2. Typhloligidium kovali sp.n., паратип +: А — правая мандибула; В — левая мандибула; C — максиллула; D — максилла; Е - максиллипед. 


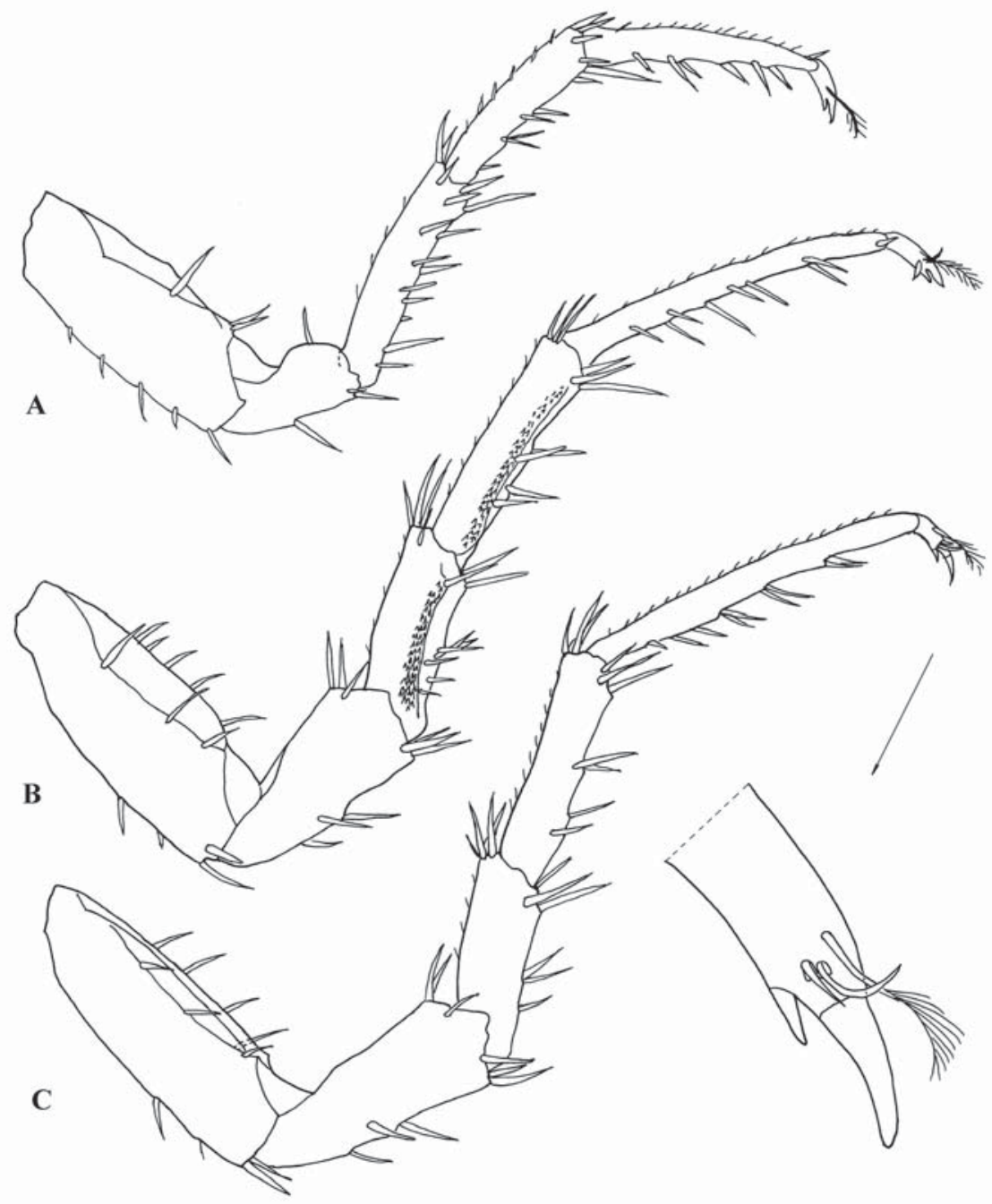

Fig. 3. Typhloligidium kovali sp. n., O paratype: A - pereopod 1; B - pereopod 6; C - pereopod 7.

Рис. 3. Typhloligidium kovali sp.n., паратип О': А - переопод 1; В - переопод 6; С - переопод 7.

part rounded or triangular with a rounded apex. Flagellum of antenna consisting of 19-23 segments. Mandibles with 15-18 free penicils, 5-6 of which placed on lacinia mobilis. Maxillule with outer branch bearing serrate inner teeth and two plumose stems at apex. Maxilliped endite with a large tooth at anterodistal corner.

REMARKS. Typhloligidium was erected by Verhoeff [1918] as a subgenus of Ligidium Brandt, 1833, to accommodate the species Ligidium coecum Carl, 1904 described from Cave Kizil-Koba in the Crimea. Borutzky [1950] upgraded Typhloligidium to the rank of a full genus and included it, together with Ligidium and two new genera, Tauroligidium Borutzky, 1950 and Caucasoligidium Borutzky, 1950, in the new subfamily Ligidiinae. A second species, Typhloligidium karabijajlae, was described by Borutzky [1962] from a cave in Karabi-Jajla, also Crimea.

Typhloligidium is readily distinguishable from Tauroligidium in having the posterior corners of pereonite
1 rounded instead of acute; from Caucasoligidium and Ligidium in lacking a piliferous field on the sides of the rear margin of the anterior pereonites; from Caucasoligidium also in shape of the distal part of the telson (rounded or triangular with a rounded apex instead of having an acute distal point). The phylogenetic relationships among the genera and subgenera of the subfamily Ligidiinae are still unassessed, also in need of a comprehensive study of molecular data.

\section{Typhloligidium kovali sp.n.}

Figs $1-4$

TYPE MATERIAL. Holotype $\Im^{\top}$ (ZMMU), Russia, central Caucasus, Republic of Kabardino-Balkaria, canyon in upper course of Nalchik River, Cave Omega-15 (NSS-53), 22.VII.2002, leg. A.G. Koval.

Paratypes: 3 우 (ZMMU), same data as holotype; $3 \sigma^{\top} \sigma^{\top}, 2$, $9+$ (MZUF 7700), same data; $1 \sigma^{7}, 2$ 우 (ZMMU), same locality, 2.VIII.2000, same collector; 1 ๙, 1 (MZUF 7701), same data; 1 + (ZMMU), same locality, 28.V.1998, same collector. 


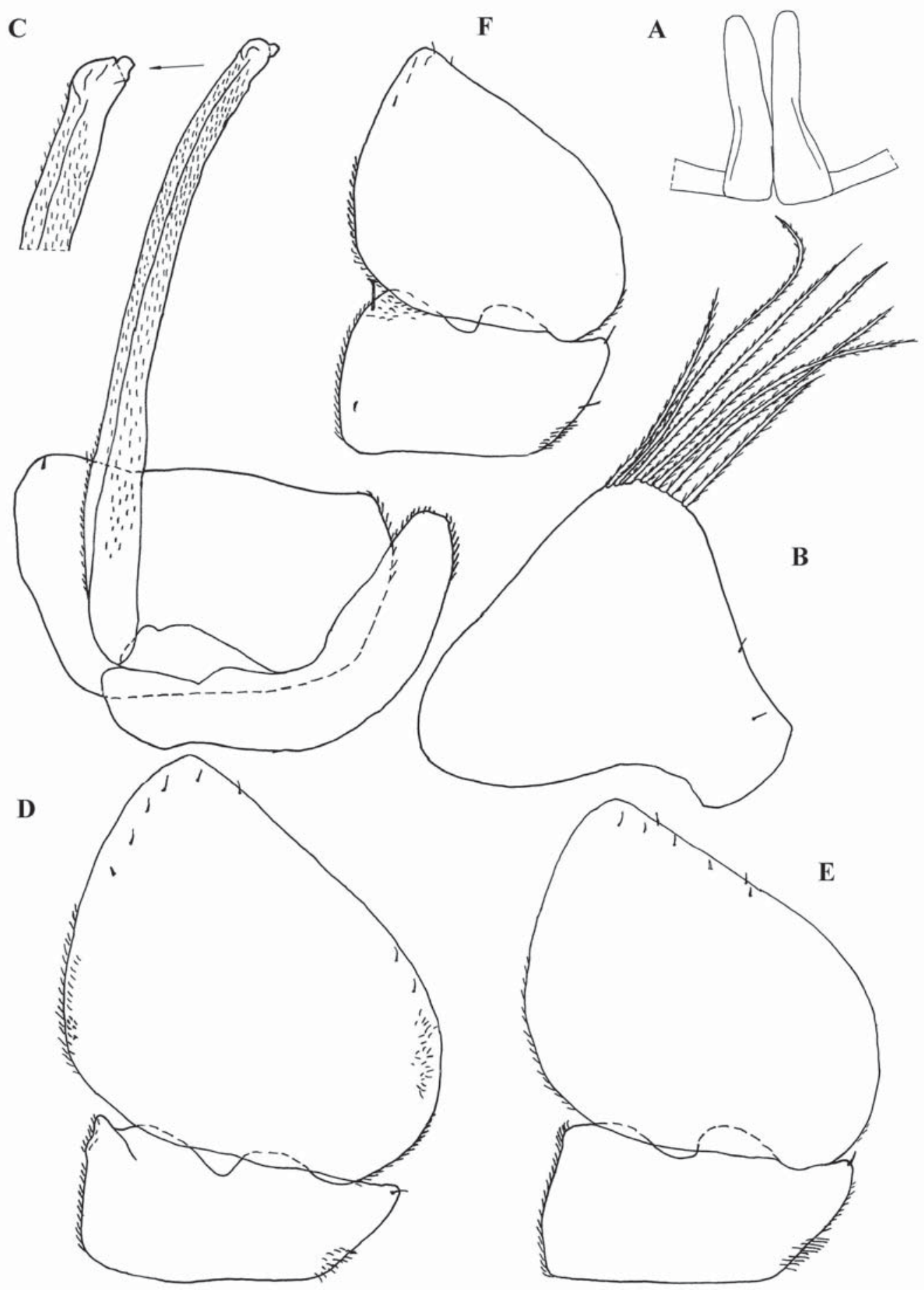

Fig. 4. Typhloligidium kovali sp.n., O paratype: A - genital papilla; B - exopod of pleopod 1; C - pleopod 2;. D - exopod of pleopod 3; E - exopod of pleopod 4; F - exopod of pleopod 5.

Рис. 4. Typhloligidium kovali sp.n., паратип $0^{7}$ : А — генитальная папилла; В — экзопод плеопода 1; C — плеопод 2; D экзопод плеопода 3; Е — экзопод плеопода 4; F — экзопод плеопода 5. 
DIAGNOSIS. A species of Typhloligidium characterized by antennal flagellum with 19 to 23 articles with distal 4-6 articles bearing a row of long aesthetascs; mandibles with 16-20 free penicils; telson broadly rounded; and $\sigma^{7}$ exopod of pleopod 1 with 6-7 long setae at apex.

DESCRIPTION. Maximum length: $\sigma^{\gamma}, 13.0 \mathrm{~mm} ;+$, $13.2 \mathrm{~mm}$. Body elongated with pleon narrower than pereon (Fig. 1A). Dorsum with some small scattered scale-setae (Fig. 1B). Cephalon (Fig. 1C-E) with supra-antennal line bent down in the middle. Posterior margin of pereonite 1 straight, of pereonites 2 and 3 increasingly concave on sides (Fig. 1A, F). Telson with posterior corners rounded and distal part broadly rounded (Fig. 1G). Antennule (Fig. 1H) with three articles; first article as broad as wide and bearing two strong setae; second longer and thinner than first, with three strong setae near apex; distal article distinctly shorter than second and first, bearing four short setae. Antenna (Fig. 1I) reaching rear margin of pereonite 6; flagellum with 19-23 articles with rows of long thin aesthetascs at base of distal 4-6 articles. Mandibles (Fig. 2A, B) with 16 to 20 penicils. Maxillule (Fig. 2C): outer branch with an outer group of 5 strong simple teeth, an inner group of 5 serrate teeth and 2 plumose stems; inner branch with 3 subequal penicils. Maxilla (Fig. 2D) with a setose and bilobate apex, outer lobe smaller; two long penicils at inner margin. Maxilliped (Fig. 2E) endite with a large tooth at anteromedial corner and four tufts of setae at apex; palp with five distinct articles, basal article with three setae near distal margin. Pereopods (Fig. 3A-C): dactylus with inner claw distinctly shorter than outer claw and dactylar seta with a hairy distal part; pereopods 6 and 7 with a poorly visible water-conducting system. Uropod (Fig. 1G) with endopod approximately the same length as exopod but distinctly more protruding backwards; endopod with two long apical setae.

$\sigma^{7}$ : Pereopods with no peculiar sexual specializations. Genital papilla double, each side elongated, with a rounded apical part (Fig. 4A). Pleopod 1 (Fig. 3B): exopod triangular, with a rounded apex bearing 6-7 very long setae, as long as exopod. Pleopod 2 (Fig. 4C): exopod subrectangular; endopod almost 3 times as long as exopod, narrow with parallel sides and a small apical lobe directed outwards. Exopods 3-5 (Fig. 4D-F) triangular, diminishing in size from 3 to 5 , with a few small setae in distal part.

ETYMOLOGY. The new species is named after Dr. A.G. Koval, St. Petersburg, who collected this species and has significantly contributed to the knowledge of the cave fauna of Russia.

REMARKS. Typhloligidium kovali sp.n. is readily distinguished from the other two species of the genus by the number of setae on the exopod of $\sigma^{7}$ pleopod 1 (6-7 instead of 4 in T. coecum or 2 in T. karabijajlae) and by the shape of the tip of the endopod of $\sigma^{7}$ pleopod 2 (cf. Fig. 4b to fig. 27 in Borutzky [1950] for T. coecus, and fig. $1 \mathrm{k}$ in Borutzky [1962] for T. karabijajlae). The discovery of the new species of Typhloligidium strongly expands the distribution range of the genus, at the moment covering both the Crimea, Ukraine and the northern Caucasus, Russia. This disjunct pattern may prove to also be filled in when caves located along the northwestern coast of the Black Sea will be properly investigated.

ACKNOWLEDGEMENTS. We thank Dr. Alexander G. Koval (St. Petersburg, Russia) for entrusting us with the material described here. The visit of KG to the Istituto per lo Studio degli Ecosistemi (Firenze, Italy) was funded by the Russian Foundation for Basic Research (grant No 11-0400245a).

\section{References}

Borutzky E.V. 1948. [Terrestrial Isopoda of the caves of the Caucasus and Crimea. II] // Vestnik Moskovskogo Gosudarstvennogo Universiteta. No.5. P.137-146 [in Russian].

Borutzky E.V. 1950. [Terrestrial Isopoda of the caves of the Caucasus and Crimea. I. Fam. Ligiidae] // Byulleten Moskovskogo Obshchestva Ispytatelei Prirody. Otdel Biol. T.55. P.69-81 [in Russian].

Borutzky E.V. 1962. [Fauna of terrestrial isopods in the caves of the Crimea in zoogeographical aspect] // Zoologicheskii Zhurnal. T.41. P.193-202 [in Russian with English summary].

Borutzky E.V. 1969. [Psachonethes czerkessicus gen. et sp. n. (Isopoda terrestria) from caves of the West Transcaucasus] // Zoologicheskii Zhurnal. T.48. P.1618-1622 [in Russian with English summary].

Borutzky E.V. 1972. [Isopoda Oniscoidea of the caves on the Black Sea coast in the Krasnodar Region] // Sbornik Trudov zoologicheskogo Muzeya. T.12. P.19-36 [in Russian].

Borutzky E.V. 1973. [The cavernicolous woodlouse fauna (Isopoda terrestria) of SSR Georgia. The family Buddelundiellidae Verhoeff, 1930] // Byulleten Moskovskogo Obshchestva Ispytatelei Prirody. Otdel Biol. T.78. P.57-62 [in Russian with English summary].

Borutzky E.V. 1974. [New genera and species of terrestrial Isopoda (Trichoniscidae) from caves of the Georgian SSR] // Zoologicheskii Zhurnal. T.53. P.338-344 [in Russian with English summary].

Borutzky E.V. 1977. [New species of the genus Trichoniscus (Crustacea, Isopoda) from Caucasian caves] // Zoologicheskii Zhurnal. T.56. P.698-703 [in Russian with English summary].

Khisametdinova D., Schmalfuss H. 2012. Three new species of Porcellium (Isopoda: Oniscidea) from the Caucasus region // Stuttgarter Beiträge zur Naturkunde. Neue Serie A. Bd.5. S..103-113.

Kuznetsova D.M., Gongalsky K.B. 2012. Cartographic analysis of woodlice fauna of the former USSR // ZooKeys. Vol.176. P. $1-11$.

Schmalfuss H. 2003a. Terrestrial isopods (Crustacea: Isopoda) from the Caucasus region. 5. Cylisticus Schnitzler, Parcylisticus Verhoeff, Cylisticoides n. gen // Stuttgarter Beiträge zur Naturkunde. Serie A. Bd.647. S.1-38.

Schmalfuss H. 2003b. World catalog of terrestrial isopods (Isopoda: Oniscidea) // Stuttgarter Beiträge zur Naturkunde. Serie A. Bd.654. S.1-341.

Vandel A. 1960. Isopodes terrestres (Première Partie). Faune de France 64. Lechevalier, Paris. 416 pp.

Responsible editor S.I. Golovatch 